\title{
Nurses' Knowledge, Practices and Attitudes about Children Safety Measures
}

\author{
Howayda Mohammed Ali ${ }^{1}$, Hekmat Ebrahim Abed-El-kreem ${ }^{2}$,Nagat Farouk Abolwafa ${ }^{3}$
}

1,3, Departments of Pediatric Nursing, Faculty of Nursing, Minia Universities, Egypt
${ }^{2}$ Department of Pediatric Nursing, Faculty of Nursing, Assiut University, Egypt
Adel_howayda@yahoo.com1, Agami202021@yahoo.com2, medonoga13@yahoo.com3

\begin{abstract}
Background: children safety is an essential and vital component of healthcare quality. Health care providers face many challenges in today's health care environment in trying to keep patients safe especially children patient safety. Nurses are well positioned to strengthen the safety net for child care within hazardous hospital environment. Aim: to assess nurses' knowledge, practices and attitudes about children safety measures. The study was a descriptive study that conducted at Pediatric Medical Departments and Critical Care Unit in Minia University Hospital for obstetrics and pediatrics, General Hospital and Masr Elhora Hospital. Sample: A convenient sample of 45 nurses was included in this study. The tools of data collection:1) Pre-designed questionnaire sheet to assess nurse's knowledge regarding children safety in hospital, 2) safety attitudequestionnaire.3) Observation checklists to assess the safety of nursing care for the children in hospital. Results: More than half of the studied nurse's have Unsatisfactory levels of knowledge related to hospital policies that improve child safety while the majority of them had Unsatisfactory levels of practices regarding children safety. There was statistical significant difference of total knowledge scores of the studied nurses regarding children safety related age, years of experience. About two third of the studied nurse's have average level of attitude related to children safety at hospital. Conclusion: that, were lacking in nurses' knowledge and practices regarding children safety measures in hospital. Recommendations: Developing periodical in services training programs regarding children safety for the nurses working at pediatric departments to improve their knowledge and practices and to be aware of the significance of child safety in their work areas.
\end{abstract}

Key Words: Nurses' practices, attitude, safety measures.

\section{Introduction}

Safety is a state of being "safe", the condition of being protected from harm or other non-desirable outcomes. Safety can also refer to the control of recognized hazards in order to achieve an acceptable level of risk. It is resulting from the modification of human behavior and designing of the physical environment to reduce hazards, thereby reducing the chance of accidents(Shekelle et al., 2011). Child safety has been broadly conceptualized as the prevention of unnecessary child harm or potential harm (World Health Organization [WHO], 2017).

In relation to this goal of harm prevention, child safety can be practically defined as the pursuit of the reduction and mitigation of unsafe acts within the healthcare system, as well as the use of best practices shown to lead to optimal child outcomes (WHO, 2014). Child safety is a global problem that calls for global solutions. Safety is emphasized as a prime concern in health system performance and quality management (Popay et al., 2014).

In view of the hospitalization, many factors are involved in the safety of children and adolescents, due to their particularities in terms of frailty, vulnerability and peculiar growth and development conditions, demanding special attention from the professionals, mainly concerning effective communication in the care process. Pediatric patient care involves the prevention of errors and the analysis of what factors caused them, with a view to implementing measures and improvements to reduce them(Boysen, 2013).In pediatrics, patient safety represents a challenge. As the probability of patient damage is three times high in hospitalized children when compared to adults (Holly, 2014).

Pediatric safety not only include effective communication but also correct identification of child as the failure to correctly identify patients continues to result in medication errors, transfusion errors, testing errors, wrong person procedures, and the discharge of infants to the wrong

$P$ a g e | 92 families (James et al., 2011). Nurses are the main group of healthcare providers in the hospital; they are generally closer to child than other clinicians and spend the most time in child care departments. As they continually oversee, coordinate and provide care, nurses are well positioned to strengthen the safety net for child care within hazardous hospital environments (Lundy, 2014).

Joint Commission International and the WHO conjointly promoting national and international children safety goals for increasing awareness about these goals and ensure safe delivery of care. The international children safety goals include the following: Improve the accuracy of children identification, Improve the effectiveness of communication among caregivers, improve the safety of high alert medications, ensure correct site, correct procedure, correct child surgery, reduce the risk of health care associated infections, reduce the risk of child harm resulting from falls(The Joint Commission, 2019).

\section{Significant of the study}

A number of countries have published studies showing that significant numbers of patients are harmed during health care, either resulting in permanent injury, increased length of stay in health care facilities, or even death (Guinea, et al., 2018). The main priority for the health system to ensure patient safety and prevent malpractice while providing quality health care (Durgun and Kaya, 2018) Patient safety is a construct that implies behavior intended to minimize the risk of harm to patients through both system effectiveness and individual performance designed to avoid injuries to patients from the care that is intend to help them. (Donaghy, et al., 2018).

According to study done in Benha Hospitals to assess nurses performance regarding child safety represented that more than half $56.4 \%$ of the studied staff nurse in medical unit don't know policy about decrease hospital acquired infection, 
$41.8 \%$ the studied nurse in medical unit incompetent done hand washing while $68.8 \%$ the studied nurse in critical unit complete done hand washing, $98.2 \%$ the studied nurse in medical unit had not done of safety of nursing care regarding suction procedure while $33.8 \%$ the studied nurse in critical unit had not done of safety of nursing care regarding suction(Bahgat et al., 2013).

\section{Aim of the Study:}

The aim of this study was to assess nurses' knowledge, practices and attitudes about children safety measures.

\section{Research question:}

- What is the nurses' knowledge, practices and attitudes about children safety measures?

- Is there a relationship between the studied nurses' personal characteristics and nurses' knowledge, practices and attitude related to children safety measures?

\section{Research design:} aim of this study

A descriptive research design was utilized to meet the

\section{Setting:}

This study was conducted at pediatric medical departments \& critical care unit in Minia University Hospital for Obstetrics \&Pediatrics, General Hospital and Masr Elhora Hospital.

\section{Sampling: \\ A convenient sample from the previously mentioned settings (45 nurses).}

\section{Tools of data collection:}

Three tools were developed by the researcher for collecting data which are:

Tool I: A structured interview questionnaire sheet in an Arabic language it was designed by the researcher after reviewing of the related literature. Tool I consist of two parts:-

Part (1): Personal data of nurses includes sex and age of nurses, qualification, years of experience ... etc (8 items).

Part (2): Nurses' knowledge related to child safety. definition of children safety, children goals in hospital, safe environment, rights of sick child, causes of accidents in hospital, risk factors which affecting child safety, international patient safety goals, nurse role in improving child safety at hospital, how to prevent bedsores, standard precautions about infection control in hospital, data should be available at identification bands, when use identification bands. After panel judgment knowledge divided into five parts:

1) It concerned with nurses knowledge about children hazards may be take place in the unit such as medication error, it consists of (4) questions about definition, causes of medication error, mistakes and management of medication error.

2) Knowledge of the studied nurses regarding fire hazard, it consists of (6) questions about; causes of fire, types of fire extinguisher, characteristics of fire extinguisher, precautions to be taken before starting use fire extinguisher, how to use fire extinguisher and fire prevention.

3) Knowledge of the studied nurses regarding electricity hazard, it was consisted of (4) questions about; definition of electricity hazards, causes of accidents resulting from the use of electricity, ways to prevent due to electricity hazards and ambulance methods in the event of an accident due to electricity.

4) Knowledge of the studied nurses regarding children falling, it consisted of (2) questions about; causes of children falling and way to children falling.

5) policy about child safety at hospital as child identification, the effectiveness of communication among caregivers, the safety of high alert medications, reduce the risk of health care associated infections, policy to reduce child fall. This last part will be used in pre/test assessment only.

Tool II: Safety Attitudes Questionnaire to measure safety attitude was consisted of 32 questions, each of the questions is answered using a 5-point Likert scale: disagree strongly (1), disagree slightly (2), neutral (3), agree slightly (4), agree strongly (5). Was adapted from (Sexton et al., 2006).

Tool III: Observational checklist was developed by the researcher that were adapted from (Healthy Children org., 2013; Hales et al; 2013)certain modifications was done by the researcher in the checklists to suit the nature of the study. It will be used to assess the safety of nursing care for the children in hospital it included the procedures of hand washing, infection control precaution, peripheral intravenous line placement, oxygen therapy and suctioning.

\section{Scoring system}

The studied nurses answers were compared with the model key answer where 2 scores was given for complete correct answer, 1 score was given for incomplete correct answer and 0 score for wrong answer and unknown answer. According to the nurse's responses, their total level of knowledge was categorized as the following: (Bahgat et al., 2013).

- $\quad$ Satisfactory level: $(\geq 75 \%)$

- Unsatisfactory level: $(50-<75 \%)$

- Don't know: $(<50 \%)$.

Scoring system for attitude of the studied nurses was calculated as the following:

All attitude variables will be weighted as (1) score for disagree strongly, (2) score for disagree slightly, (3) score for neutral, (4) score for agree slightly, (5) score for agree strongly.

- Negative attitude (1-54)

- $\quad$ Average attitude (55-107)

- $\quad$ Good attitude (108-160)

Scoring system for practicing nursing care will be calculated as the following:

Performances step will be weighted as: 0 for not done, 1 for incomplete done and 2 for completely done, for each procedure total score was scored as: (Bahgat et al., 2013).

- Complete: $(\geq 75 \%)$

- Incomplete: $(50-<75 \%)$

- Not done: $(<50 \%)$.

Howayda M., et al 


\section{Validity:}

The tool was tested for content validity by a jury of five experts in field of pediatric nursing and necessary modifications were done. The tool was tested for internal consistency after developing the tools.

\section{Reliability:}

Reliability of the tools was performed to confirm its consistency by using Cronbach's alpha test. It was $(0.79)$ for Structured interviewing questionnaire and knowledge of the studied nurses regarding child safety, (0.83) for tool two which assessing attitude of the studied nurses relate children safety and (0.86) for tool three which assessing practices of the studied nurses related to children safety.

\section{Pilot study:}

After developing the tools, a pilot study was conducted on 5 nurses ( $10 \%$ of the total sample). A pilot study was conducted for purpose to testing clarity, completeness and to determine the time involvement. Results of the pilot study illustrated that no any refinements and modifications needed so the subjects were include to the actual sample.

\section{Ethical Consideration:}

A written approval was obtained from the research ethical committee of the Faculty of Nursing, Minia University. The purpose of this study was explained for every nurse each nurse has right to agree or refuse participation in the study. Oral informed consent was obtained from nurses who participated in this study. They also informed that the information obtained will be confidential and will be used only for the purpose of the study. Each assessment sheet was coded and nurses' name did not appear on the sheets in the purpose of anonymity and confidentiality.

\section{Field Work}

An official permission to conduct the proposed study was obtained by the researcher from the manager of Minia University, General Hospitals and Masr Elhora Hospital. Also the official approval for data collection was obtained from the medical and pediatric critical care consultants of the study setting after explanation of the purpose of the study. Also verbal consent was obtained from each nurses participated in the study. Clarification of the nature and purpose of the study was done on initial interview with each nurse.

Collection of data was started from the beginning of July 2018 to the end of January 2019, two days per week from 9 am: 12 pm by rotation at each study setting.

\section{Statistical analysis:}

Data entry was done using compatible personal computer. The statistical - analysis was done using SPSS-20 statistical software package and Excel for figures. The content of each tool was coded, categorized then analyzed. Data were presented using descriptive statistics in the form of frequencies and percentages for qualitative variables and means and standard deviations for quantitative variables. The qualitative studied variables were compared using Chi-square test. Statistical significance used at $\mathrm{P}$. value $<0.05$.

\section{Results:}

Table (1): Distribution of the Studied Nurses according to their Socio- Demographic Characteristics (No. $=45)$ :

\begin{tabular}{|c|c|c|}
\hline Item & No. & $\%$ \\
\hline \multicolumn{3}{|l|}{ Age } \\
\hline$>20$ & 11 & 24.4 \\
\hline $20<30$ & 22 & 48.9 \\
\hline $30<40$ & 12 & 26.7 \\
\hline$>40$ & 0 & 0 \\
\hline Mean \pm SD & \multicolumn{2}{|c|}{$27.22 \pm 16.227$ years } \\
\hline \multicolumn{3}{|l|}{ Sex } \\
\hline Male & 10 & 22.2 \\
\hline Female & 35 & 77.6 \\
\hline \multicolumn{3}{|l|}{ Qualification } \\
\hline Diploma of nursing & 22 & 48.9 \\
\hline Diploma of technical institute & 21 & 46.7 \\
\hline Bachelor degree in nursing & 2 & 4.4 \\
\hline Postgraduate studies in nursing & 0 & 0 \\
\hline \multicolumn{3}{|l|}{ Years of experience } \\
\hline $1<5$ & 14 & 31.1 \\
\hline $5<10$ & 19 & 42.2 \\
\hline$\geq 10$ & 12 & 26.7 \\
\hline Mean \pm SD & \multicolumn{2}{|c|}{$\frac{1}{7.56 \pm 11.674}$} \\
\hline \multicolumn{3}{|l|}{ Hospital name } \\
\hline Minia University Hospital for Obstetrics \&Pediatrics & 25 & 55.6 \\
\hline General Hospital & 10 & 22.2 \\
\hline Masr Elhora Hospital & 10 & 22.2 \\
\hline \multicolumn{3}{|l|}{ Working units } \\
\hline Pediatric unit & 35 & $\mathbf{7 7 . 8}$ \\
\hline Pediatric ICU & 10 & 22.2 \\
\hline \multicolumn{3}{|c|}{ Attendance of training programs related to children safety at hospital } \\
\hline - $\quad$ NO & 43 & 95.6 \\
\hline YES & 2 & 4.4 \\
\hline
\end{tabular}

Table (1): Illustrated that more than half (55.6\%) of the studied nurses was working in Minia University Hospital for obstetrics \& pediatrics, while more than two fifth $(48.9 \%)$ of the studied nurses had age $20<30$ years old with a mean of age $27.22 \pm$ 16.227 years. Less than half $(48.9 \%)$ of the studied nurses their qualification was diploma of nursing, On the other hand, the highest 
percentage of the studied nurses (77.8\%) were working in Pediatric unit and didn't attending any training programs related to children safety $(95.6 \%)$. The mean years of experience of the nurses was $7.56 \pm 11.674$ year.

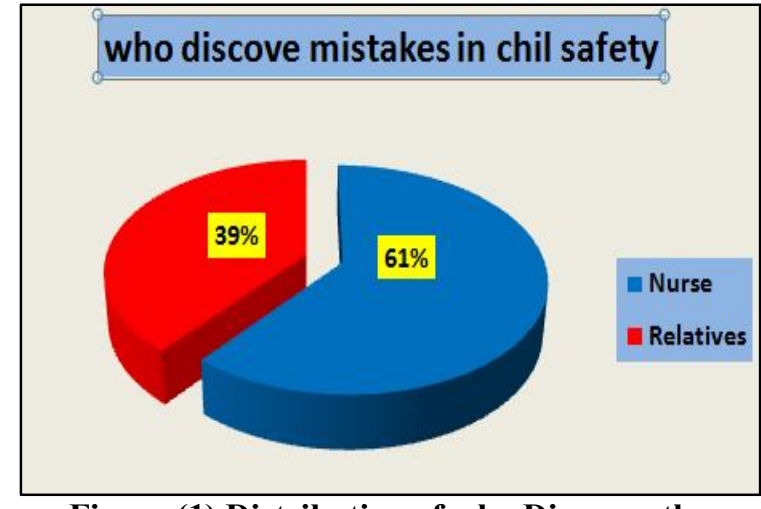

Figure (1) Distribution of who Discover the Mistakes in Child Safety: (No. $=45)$.



Figure (2) Distribution of the Way to Discover Mistakes in Nursing Care: (No. $=45)$.

Figure (1 \& 2): showed that more than half of the studied nurses $(61 \%)$ answered that the person who discover mistakes in child safety was the nurse, while three quarters (75\%) of them answered that the way to discover mistakes in child safety was by luck.

Table (2): Frequency Distribution of the Studied Nurses regarding their Knowledge about Hospital Policies that Improve Child Safety: $($ No. $=45)$.

\begin{tabular}{|c|c|c|c|c|c|c|}
\hline \multirow{2}{*}{$\begin{array}{l}\text { Knowledge of the studied nurses regarding hospital policies that improve child } \\
\text { safety }\end{array}$} & \multicolumn{2}{|c|}{$\begin{array}{c}\text { Complete correct } \\
\text { answer } \\
\end{array}$} & \multicolumn{2}{|c|}{$\begin{array}{c}\text { Incomplete } \\
\text { correct answer }\end{array}$} & \multicolumn{2}{|c|}{$\begin{array}{l}\text { Don't } \\
\text { know }\end{array}$} \\
\hline & No. & $\%$ & No. & $\%$ & No. & $\%$ \\
\hline Child identification in correct way & 8 & 17.8 & 37 & 82.2 & 0 & 0.0 \\
\hline Improving methods of effective communication & 9 & 20.0 & 36 & 80.0 & 0 & 0.0 \\
\hline Decrease hospital acquired infection & 1 & 2.2 & 33 & $\mathbf{7 3 . 3}$ & 11 & 24.4 \\
\hline Safety uses of drugs which highly dangerous & 9 & 20.0 & 32 & 71.1 & 4 & 8.9 \\
\hline Decrease child fall down injuries & 5 & 11.1 & 33 & 73.3 & 7 & 15.6 \\
\hline
\end{tabular}

Table (2): indicates that the majority of the studied nurses $82.2 \%, 80 \%, 73.3 \%, 71.1 \%, 73.3 \%$ respectively, had incomplete knowledge regarding hospital policies about child identification in correct way, improving methods of effective communication, decrease hospital acquired infection, safety uses of drugs which highly dangerous and decrease child fall down injuries respectively, while $24.4 \%, 15.6 \%$ of the studied nurses don't know hospital policy regarding decreasing hospital acquired infection and decreasing child fall down injuries respectively.

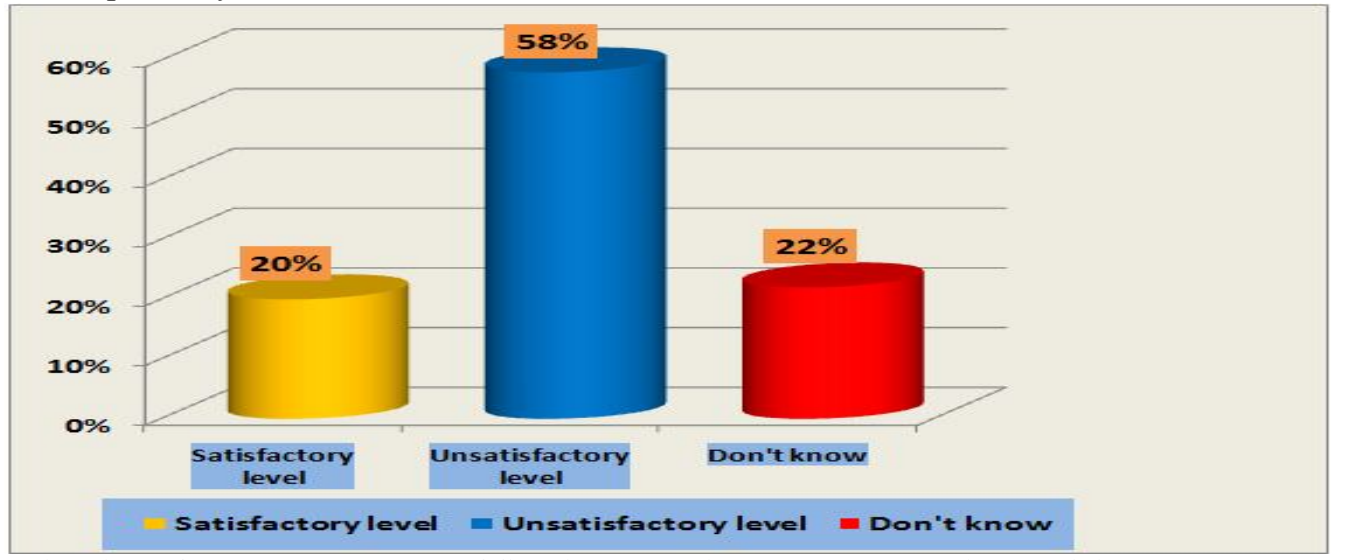

Figure (3): Distribution of Total Knowledge of Studied Nurse's related to Hospital Policies that Improve Child Safety

Figure (3): Illustrate that, more than half $(58 \%)$ of the studied nurseshave unsatisfactory levels of knowledge related to hospital policies that improve child safety.

Table (3): The Relation between Total Knowledge of Studied Nurse's related to Children Safety in Hospital and their Personal Characteristics $n=45$

\begin{tabular}{|c|c|c|c|c|c|c|c|c|}
\hline \multirow{3}{*}{ Item } & \multicolumn{6}{|c|}{ Knowledge } & \multirow[t]{3}{*}{$\mathbf{X} 2$} & \multirow[t]{3}{*}{ P. value } \\
\hline & \multicolumn{2}{|c|}{$\begin{array}{c}\text { Satisfactory } \\
\text { level }\end{array}$} & \multicolumn{2}{|c|}{$\begin{array}{c}\text { unsatisfactory } \\
\text { level }\end{array}$} & \multicolumn{2}{|c|}{ Don't know } & & \\
\hline & No & $\%$ & No & $\%$ & No & $\%$ & & \\
\hline $\begin{array}{l}\text { age(year) } \\
\cdot \quad>20 \\
\text { - } 20<30 \\
\text { - } 30<40 \\
\end{array}$ & $\begin{array}{l}0 \\
0 \\
0\end{array}$ & $\begin{array}{l}0.0 \\
0.0 \\
0.0\end{array}$ & $\begin{array}{c}1 \\
12 \\
3\end{array}$ & $\begin{array}{c}2.2 \\
26.7 \\
6.7\end{array}$ & $\begin{array}{c}10 \\
10 \\
9\end{array}$ & $\begin{array}{c}22.2 \\
22.2 \\
20\end{array}$ & 7.408 & $0.02 *$ \\
\hline $\begin{array}{l}\text { Sex } \\
\text { - Male } \\
\text { - Female }\end{array}$ & $\begin{array}{l}0 \\
0\end{array}$ & $\begin{array}{l}0.0 \\
0.0\end{array}$ & $\begin{array}{c}4 \\
12\end{array}$ & $\begin{array}{c}8.8 \\
26.7\end{array}$ & $\begin{array}{c}6 \\
23\end{array}$ & $\begin{array}{l}13.3 \\
51.2\end{array}$ & .111 & 0.73 \\
\hline
\end{tabular}




\begin{tabular}{|c|c|c|c|c|c|c|c|c|}
\hline \multirow{3}{*}{ Item } & \multicolumn{6}{|c|}{ Knowledge } & \multirow[t]{3}{*}{$\mathrm{X} 2$} & \multirow[t]{3}{*}{ P. value } \\
\hline & \multicolumn{2}{|c|}{$\begin{array}{c}\text { Satisfactory } \\
\text { level }\end{array}$} & \multicolumn{2}{|c|}{$\begin{array}{c}\text { unsatisfactory } \\
\text { level }\end{array}$} & \multicolumn{2}{|c|}{ Don't know } & & \\
\hline & No & $\%$ & No & $\%$ & No & $\%$ & & \\
\hline $\begin{array}{l}\text { Qualification } \\
\text { - Diploma of nursing } \\
\text { - Diploma of technical institute } \\
\text { - Bachelor degree in nursing }\end{array}$ & $\begin{array}{l}0 \\
0 \\
0\end{array}$ & $\begin{array}{l}0.0 \\
0.0 \\
0.0\end{array}$ & $\begin{array}{c}5 \\
10 \\
1\end{array}$ & $\begin{array}{c}11.2 \\
22.2 \\
2.2\end{array}$ & $\begin{array}{c}17 \\
11 \\
1\end{array}$ & $\begin{array}{c}37.8 \\
24.4 \\
2.2\end{array}$ & 3.096 & 0.213 \\
\hline $\begin{array}{l}\text { Years of experience } \\
\text { - } \quad 1<5 \\
\text { - } \quad 5<10 \\
\text { - } \quad \geq 10\end{array}$ & $\begin{array}{l}0 \\
0 \\
0\end{array}$ & $\begin{array}{l}0.0 \\
0.0 \\
0.0\end{array}$ & $\begin{array}{c}1 \\
12 \\
3\end{array}$ & $\begin{array}{c}2.2 \\
26.7 \\
6.7\end{array}$ & $\begin{array}{c}13 \\
7 \\
9\end{array}$ & $\begin{array}{c}28.8 \\
15.6 \\
20\end{array}$ & 11.834 & $0.003 * *$ \\
\hline $\begin{array}{l}\text { Hospital name } \\
\text { - Minia University Hospital for obstetrics \& pediatrics } \\
\text { - General Hospital } \\
\text { Masr Elhora Hospital }\end{array}$ & $\begin{array}{l}0 \\
0 \\
0\end{array}$ & $\begin{array}{l}0.0 \\
0.0 \\
0.0\end{array}$ & $\begin{array}{l}9 \\
4 \\
3\end{array}$ & $\begin{array}{l}20 \\
8.8 \\
6.7\end{array}$ & $\begin{array}{c}16 \\
6 \\
7\end{array}$ & $\begin{array}{l}35.6 \\
13.3 \\
15.6\end{array}$ & .223 & .894 \\
\hline
\end{tabular}

Table (3): Clarified that there was highly statistical significance relation between total knowledge score of studied nurse's regarding children safety in hospital related to years of experience $(\mathrm{P}<0.001)$, statistical significance relation age $(\mathrm{P}<0.05)$ and there was no statistical significance relation in sex, qualification \& hospital name.

Table (4): The Relation between Total Knowledge of Studied Nurse's related to Medication Error and their Personal Characteristics $n=45$

\begin{tabular}{|c|c|c|c|c|c|c|c|c|}
\hline \multirow{3}{*}{ Item } & \multicolumn{6}{|c|}{ knowledge } & \multirow{3}{*}{$\mathrm{X} 2$} & \multirow{3}{*}{$\begin{array}{c}P . \\
\text { value }\end{array}$} \\
\hline & \multicolumn{2}{|c|}{$\begin{array}{c}\text { Satisfactory } \\
\text { level }\end{array}$} & \multicolumn{2}{|c|}{$\begin{array}{c}\text { Unsatisfactory } \\
\text { level }\end{array}$} & \multicolumn{2}{|c|}{$\begin{array}{l}\text { Don't } \\
\text { know }\end{array}$} & & \\
\hline & No & $\%$ & No & $\%$ & No & $\%$ & & \\
\hline $\begin{array}{l}\text { age(year) } \\
\cdot \quad>20 \\
\text { - } \quad 20<30 \\
\text { - } \quad 30<40 \\
\end{array}$ & $\begin{array}{l}0 \\
0 \\
0\end{array}$ & $\begin{array}{l}0.0 \\
0.0 \\
0.0\end{array}$ & $\begin{array}{c}2 \\
19 \\
9\end{array}$ & $\begin{array}{c}4.4 \\
42.2 \\
20\end{array}$ & $\begin{array}{l}9 \\
3 \\
3\end{array}$ & $\begin{array}{l}20 \\
6.7 \\
6.7\end{array}$ & 15.85 & $\begin{array}{c}0.000^{*} \\
*\end{array}$ \\
\hline $\begin{array}{l}\text { Sex } \\
\text { - } \text { Male } \\
\text { - Female }\end{array}$ & $\begin{array}{l}0 \\
0\end{array}$ & $\begin{array}{l}0.0 \\
0.0\end{array}$ & $\begin{array}{l}10 \\
20\end{array}$ & $\begin{array}{l}22.2 \\
44.4\end{array}$ & $\begin{array}{c}0 \\
15\end{array}$ & $\begin{array}{c}0.0 \\
33.4\end{array}$ & 6.42 & $0.01 *$ \\
\hline $\begin{array}{l}\text { Qualification } \\
\text { - } \text { Diploma of nursing } \\
\text { - } \text { Diploma of technical institute } \\
\text { - } \text { Bachlora degree in nursing } \\
\end{array}$ & $\begin{array}{l}0 \\
0 \\
0\end{array}$ & $\begin{array}{l}0.0 \\
0.0 \\
0.0\end{array}$ & $\begin{array}{c}18 \\
10 \\
2\end{array}$ & $\begin{array}{c}40 \\
22.2 \\
4.4\end{array}$ & $\begin{array}{c}4 \\
11 \\
0\end{array}$ & $\begin{array}{c}8.9 \\
24.5 \\
0.0\end{array}$ & 6.701 & $0.03 *$ \\
\hline $\begin{array}{l}\text { Years of experience } \\
\text { : } \quad 1<5 \\
\text { - } \quad 5<10 \\
\text {. } \geq 10\end{array}$ & $\begin{array}{l}0 \\
0 \\
0\end{array}$ & $\begin{array}{l}0.0 \\
0.0 \\
0.0\end{array}$ & $\begin{array}{c}2 \\
19 \\
9\end{array}$ & $\begin{array}{c}4.4 \\
42.2 \\
20\end{array}$ & $\begin{array}{c}12 \\
0 \\
3\end{array}$ & $\begin{array}{c}26.7 \\
0.0 \\
6.7\end{array}$ & 27.16 & $\begin{array}{c}0.000^{*} \\
*\end{array}$ \\
\hline $\begin{array}{l}\text { Hospital name } \\
\text { - Minia University Hospital for obstetrics \& pediatrics } \\
\text { - General Hospital } \\
\text { Masr Elhora Hospital }\end{array}$ & $\begin{array}{l}0 \\
0 \\
0\end{array}$ & $\begin{array}{l}0.0 \\
0.0 \\
0.0\end{array}$ & $\begin{array}{c}16 \\
8 \\
6\end{array}$ & $\begin{array}{l}35.6 \\
17.8 \\
13.3\end{array}$ & $\begin{array}{l}9 \\
2 \\
4\end{array}$ & $\begin{array}{c}20 \\
4.4 \\
8.9\end{array}$ & 1.08 & .583 \\
\hline
\end{tabular}

Table (4): Clarified that there was highly statistical significance relation between total knowledge score of studied nurse's regarding medication error related to age, and years of experience $(\mathrm{P}<0.001)$, statistical significance relation sex and qualification $(\mathrm{P}$ $<0.05$ )and there was no statistical significance relation with hospital name.

Table (5): The Relation between Total Knowledge of Studied Nurse's related to Electrical Hazard and their Personal Characteristics $n=45$

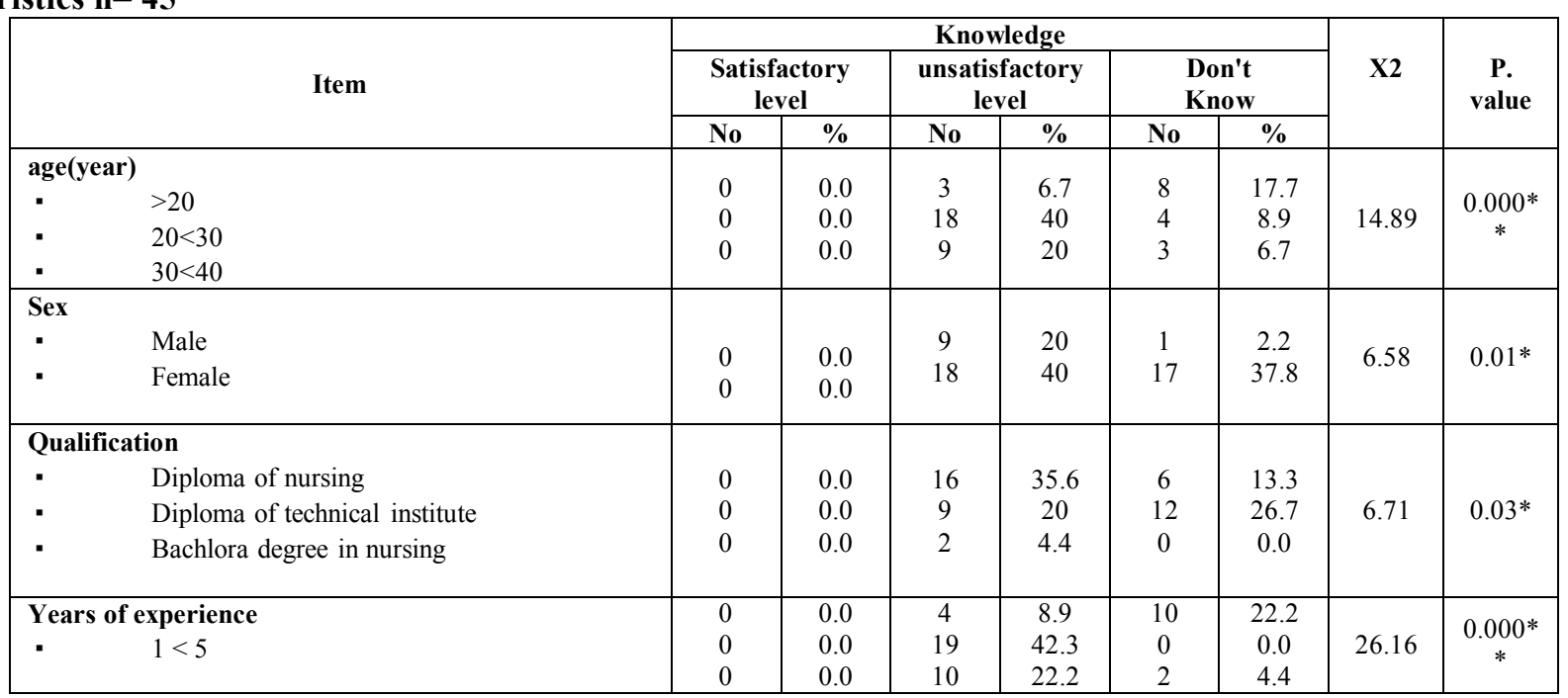




\begin{tabular}{|c|c|c|c|c|c|c|c|c|}
\hline \multirow{3}{*}{ Item } & \multicolumn{6}{|c|}{ Knowledge } & \multirow{3}{*}{$\mathrm{X} 2$} & \multirow{3}{*}{$\begin{array}{c}P . \\
\text { value }\end{array}$} \\
\hline & \multicolumn{2}{|c|}{$\begin{array}{c}\text { Satisfactory } \\
\text { level }\end{array}$} & \multicolumn{2}{|c|}{$\begin{array}{c}\text { unsatisfactory } \\
\text { level }\end{array}$} & \multicolumn{2}{|c|}{$\begin{array}{l}\text { Don't } \\
\text { Know }\end{array}$} & & \\
\hline & No & $\%$ & No & $\%$ & No & $\%$ & & \\
\hline $\begin{array}{ll}\cdot & 5<10 \\
\text { - } & \geq 10\end{array}$ & & & & & & & & \\
\hline $\begin{array}{l}\text { Hospital name } \\
\text { - Minia University Hospital for obstetrics \& pediatrics } \\
\text { - General Hospital } \\
\text { Masr Elhora Hospital }\end{array}$ & $\begin{array}{l}0 \\
0 \\
0\end{array}$ & $\begin{array}{l}0.0 \\
0.0 \\
0.0\end{array}$ & $\begin{array}{l}16 \\
8 \\
6\end{array}$ & $\begin{array}{l}35.6 \\
17.8 \\
13.3\end{array}$ & $\begin{array}{l}9 \\
2 \\
4\end{array}$ & $\begin{array}{l}20 \\
4.4 \\
8.9\end{array}$ & 1.08 & .583 \\
\hline
\end{tabular}

Table (5): Clarified that there was highly statistical significance relation between total knowledge score of studied nurse's regarding electrical hazards related to age, and years of experience $(\mathrm{P}<0.001)$, statistical significance relation sex and qualification $(\mathrm{P}$ $<0.05)$ and there was no statistical significance relation with hospital name.

Table (6): The Relation between Total Attitude of Studied Nurse's and their Personal Characteristics n= 45

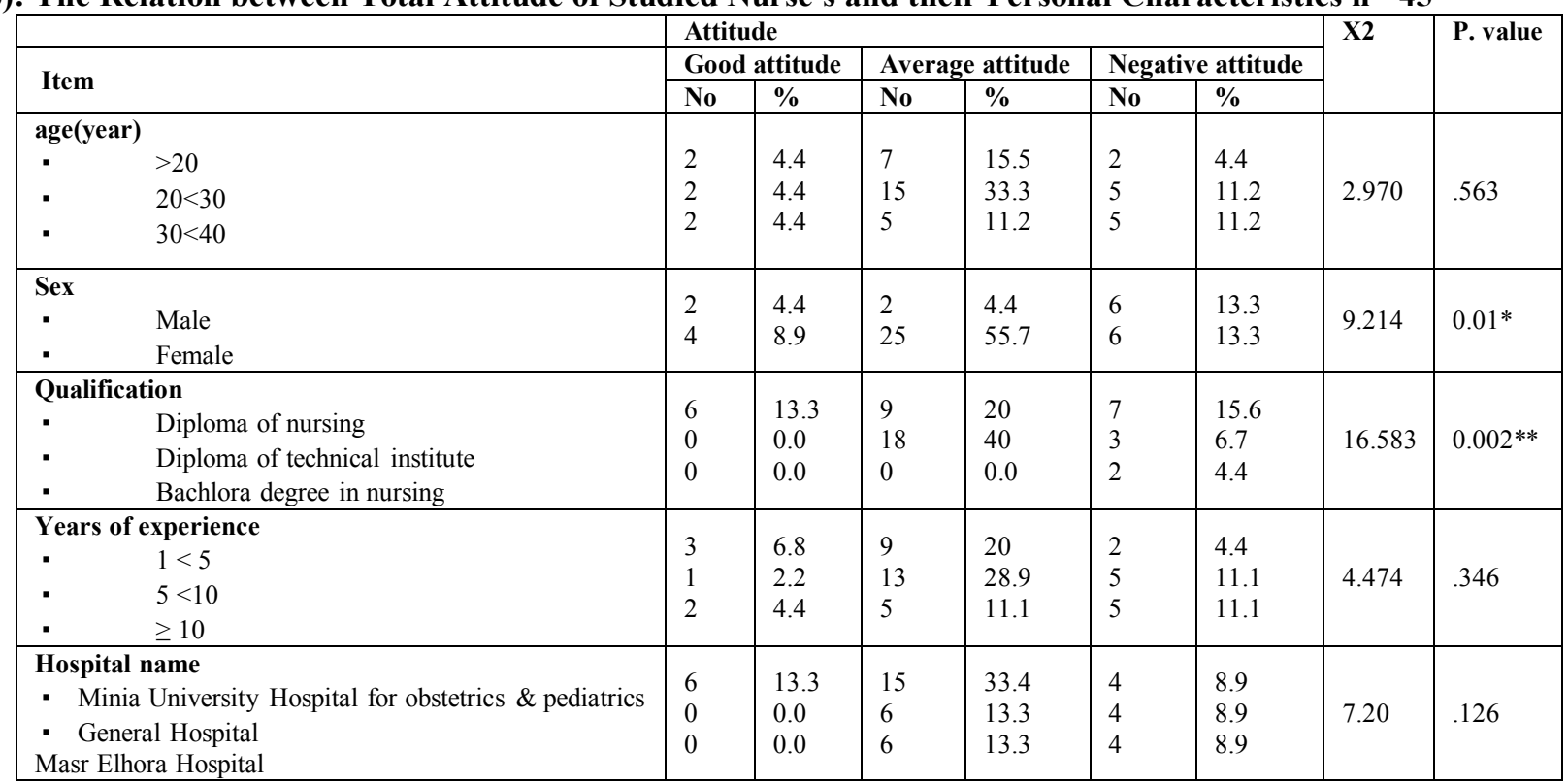

Table (6): Clarified that there was highly statistical significance relation between total attitude of studied nurse's and qualification $(\mathrm{P}<0.001)$, statistical significance related to $\operatorname{sex}(\mathrm{P}<0.05)$ and no statistical significance relation age, years of experience\& hospital name .

Table (7): The Relation between Total Practices of Studied Nurse's and their Personal Characteristics $n=45$

\begin{tabular}{|c|c|c|c|c|c|c|c|c|}
\hline \multirow{3}{*}{ Item } & \multicolumn{6}{|c|}{ practices } & \multirow{3}{*}{$\mathrm{X} 2$} & \multirow{3}{*}{$\begin{array}{c}P . \\
\text { value }\end{array}$} \\
\hline & \multicolumn{2}{|c|}{ Satisfactory } & \multicolumn{2}{|c|}{$\begin{array}{c}\text { Unsatisfacto } \\
\text { ry }\end{array}$} & \multicolumn{2}{|c|}{ Don't Know } & & \\
\hline & No & $\%$ & No & $\%$ & No & $\%$ & & \\
\hline $\begin{array}{l}\text { age(year) } \\
\cdot \quad 20 \\
\text {. } \quad 20<30 \\
\text { - } 30<40\end{array}$ & $\begin{array}{l}0 \\
0 \\
0\end{array}$ & $\begin{array}{l}0.0 \\
0.0 \\
0.0\end{array}$ & $\begin{array}{c}9 \\
17 \\
11\end{array}$ & $\begin{array}{c}20 \\
37.8 \\
24.5\end{array}$ & $\begin{array}{l}2 \\
5 \\
1\end{array}$ & $\begin{array}{c}4.4 \\
11.1 \\
2.2\end{array}$ & 1.102 & 0.576 \\
\hline $\begin{array}{l}\text { Sex } \\
\text { - Male } \\
\text { - Female }\end{array}$ & $\begin{array}{l}0 \\
0\end{array}$ & $\begin{array}{l}0.0 \\
0.0\end{array}$ & $\begin{array}{c}8 \\
29\end{array}$ & $\begin{array}{l}17.8 \\
64.5\end{array}$ & $\begin{array}{l}2 \\
6\end{array}$ & $\begin{array}{c}4.4 \\
13.3\end{array}$ & .043 & 0.835 \\
\hline $\begin{array}{l}\text { Qualification } \\
\text { - Diploma of nursing } \\
\text { - Diploma of technical institute } \\
\text { - Bachelor degree in nursing }\end{array}$ & $\begin{array}{l}0 \\
0 \\
0\end{array}$ & $\begin{array}{l}0.0 \\
0.0 \\
0.0\end{array}$ & $\begin{array}{c}18 \\
17 \\
2\end{array}$ & $\begin{array}{c}40 \\
37.8 \\
4.4\end{array}$ & $\begin{array}{l}4 \\
4 \\
0\end{array}$ & $\begin{array}{l}8.9 \\
8.9 \\
0.0\end{array}$ & .458 & 0.795 \\
\hline $\begin{array}{l}\text { Years of experience } \\
\text { - } \quad 1<5 \\
\text { - } \quad 5<10 \\
\text { - } \geq 10 \\
\end{array}$ & $\begin{array}{l}0 \\
0 \\
0\end{array}$ & $\begin{array}{l}0.0 \\
0.0 \\
0.0\end{array}$ & $\begin{array}{l}12 \\
14 \\
11\end{array}$ & $\begin{array}{l}26.7 \\
31.1 \\
24.5\end{array}$ & $\begin{array}{l}2 \\
5 \\
1\end{array}$ & $\begin{array}{c}4.4 \\
11.1 \\
2.2\end{array}$ & 1.797 & 0.407 \\
\hline $\begin{array}{l}\text { Hospital name } \\
\text { - Minia University Hospital for obstetrics \& pediatrics } \\
\text { - General Hospital } \\
\text { - } \quad \text { Masr Elhora Hospital } \\
\end{array}$ & $\begin{array}{l}0 \\
0 \\
0\end{array}$ & $\begin{array}{l}0 \\
0 \\
0\end{array}$ & $\begin{array}{c}25 \\
8 \\
4\end{array}$ & $\begin{array}{l}67.6 \\
21.6 \\
10.8\end{array}$ & $\begin{array}{l}0 \\
2 \\
6\end{array}$ & $\begin{array}{l}0.0 \\
25 \\
75\end{array}$ & 17.635 & $.000 * *$ \\
\hline
\end{tabular}

Table (7): Clarified that there was no statistical significance relation between total practices score of studied nurse's and their personal characteristics except with hospital name there was highly statistical significance relation $(\mathrm{P}<0.001)$. 


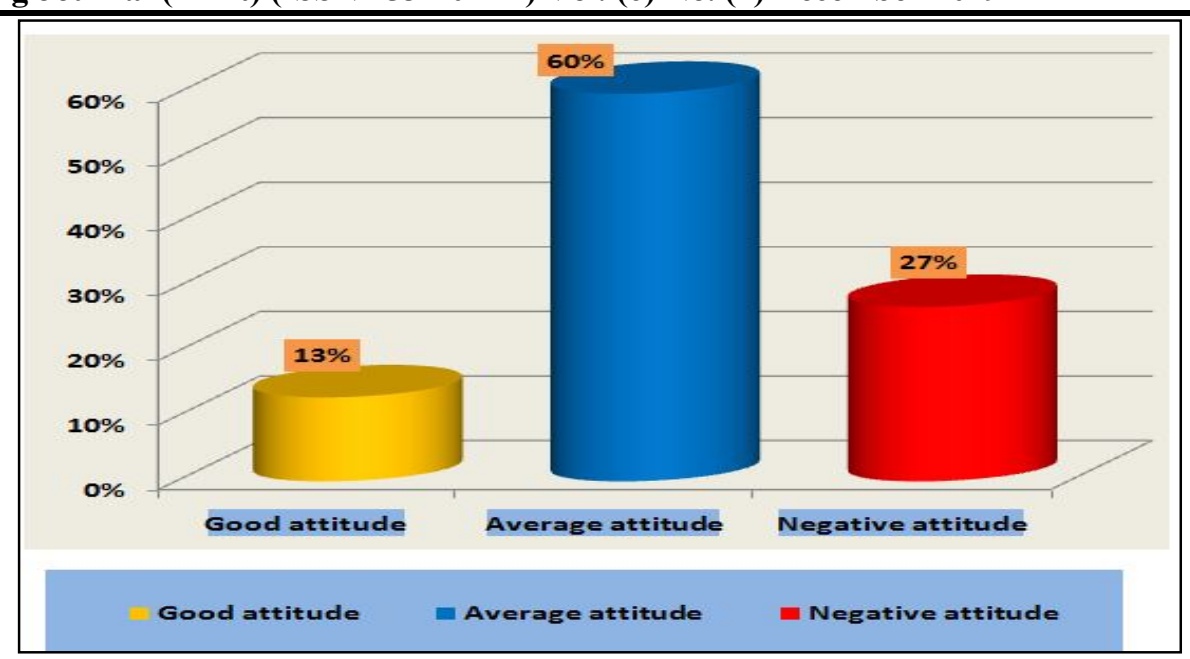

Figure (4): Distribution of Total Nurses' Attitude toward Children Safety at Hospital hospital.

Figure (4): show that two third $(60 \%)$ of the studied nurses have average level of attitude related to children safety at

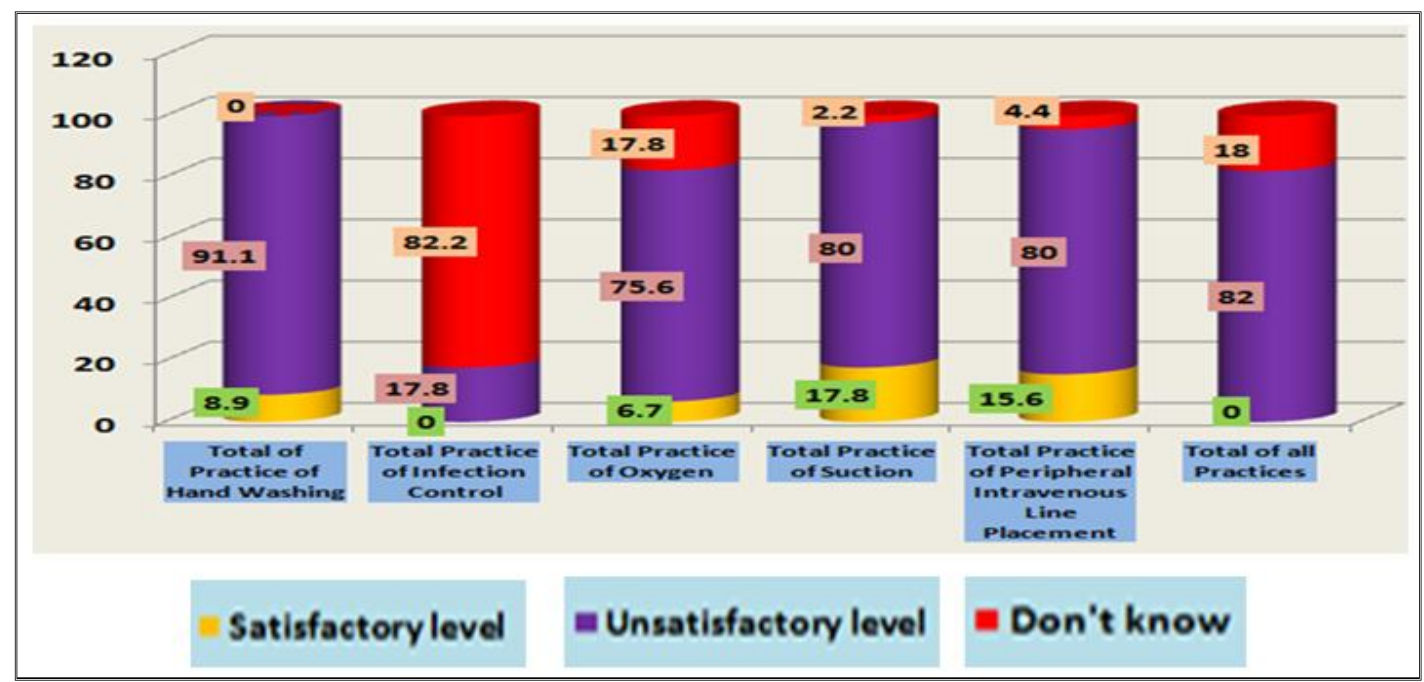

Figure (5): Distribution of Total Practices of Studied Nurse's related to Hand Washing, Infection Control, Oxygen Therapy, Suction, Peripheral Intravenous Line Placement Procedures and Total of all Practices related to Children Safety in Hospitals:

Figure (5): Illustrate that, the majority $(91 \%, 76 \%, 80 \%, 80 \%$ and $82 \%)$ of the studied nurses have unsatisfactory level of practice related to hand washing, oxygen therapy, suction, peripheral intravenous line placement procedures and total of all practices related to children safety in hospitals, while (82\%) of them don't know.

\section{Discussion:}

Child safety has been broadly conceptualized as the prevention of unnecessary child harm or potential harm. In relation to this goal of harm prevention, child safety can be practically defined as the pursuit of the reduction and mitigation of unsafe acts within the healthcare system, as well as the use of best practices shown to lead to optimal child outcomes (World Health Organization, 2017). Child safety is a global problem that calls for global solutions. Safety is emphasized as a prime concern in health system performance and quality management (Meckler, et al., 2014). The aim of this study was to: Assess the nurses' performances and attitude regarding children safety measures.

In the present study, the majority of the study nurses were female and less than half of the studied nurses age were ranged from $20<30$ years old with a mean of age27.22 years and less than half of them have current job experience $5>10$ years and all of them didn't attending training programs related to children safety These findings are corroborated by findings of by Ahmed, (2013) \& Fayed et al., (2018) who reported that was $53.2 \%$ of them were females, $42.6 \%$ of staff nurses had experience between $5>10$ years in nursing flied and
$78 \%$ of staff nurses didn't attending training programs related to children safety this may be due to improper provision of training programs conduction, and lack of supervisor awareness about the importance of safety. The training programs play important role in enhancing child safety and updating the nurse's knowledge, practice and improving attitude toward children safety. The researcher believes that attending training and educational programs by nurses especially in pediatrics unit is crucial to enhance children safety during nursing care.

Regarding discovering the mistakes in child safety and way to discover the mistakes, the finding of the current study showed that more than half of the studied nurses answered that the person who discover mistakes in child safety was the nurse, and three quarters of the studied nurses answered that the way to discover mistakes in child safety was by luck, this finding is similar to results of Bahgat, et al.,(2013) entitled of " Nurses' Perception and Developing an Improvement Plan Regarding Child Safety in Benha Hospitals "who found that, the majority of them discover mistakes by luck. 
In relation to knowledge about hospital policies that improve child safety, the present study revealed that the majority of the studied nurses had incomplete correct answer knowledge regarding hospital policies about child identification in correct way, improving methods of effective communication, decrease hospital acquired infection, safety uses of drugs which highly dangerous and decrease child fall down injuries and more than half of them had unsatisfactory level of knowledge about hospital policies that improve child safety. This finding was agreed with Bahgatetal., (2013): who found that, half of the studied staff nurse don't know hospital policy regarding child identification and decrease hospital acquired infection. This finding was disagree with National Patient Safety Foundation (2013), who pointed out that the nurse should use at least two identifier when providing care, treatment and services to eliminate transfusion errors related to child misidentification. This finding was disagreed with National Patient Safety Foundation (2013), who mentioned that the nurse should comply with infection control guidelines of WHO to prevent infections due to multi-drug-resistant organisms and prevent central-line-associated blood stream infections.

During studying relationship between the nurse's knowledge (children safety in hospital, medication error, electrical hazard), attitude, practice and their socio demographic data the present study results revealed that there was statistical significant relation between the nurses' knowledge \&attitude and their socio demographic characteristics but no statistical significant relation between the nurses' practices and their socio demographic characteristics except with hospital name. Moreover, the study results agreed with Fayed et al., (2018): who found that there were statistical significance association between the nurse's knowledge \& practices and their socio demographic data except with work unit there was no statistical significance association.

The present study revealed that, about two third of the studied nurses have average attitude. This finding was similar to Fayed et al., (2018): who found that (68.7) of studied nurses had uncertain attitude related to children safety measure in hospital. Also Brasaite et al., (2015) found that the studied nurses had positive safety attitudes.

In relation to the practices of studied nurses about child safety measures, the present study showed that, the majority of the studied nurses have unsatisfactory practices related to children safety. These findings were supported by the results of the study done by Fayed et al., (2018), who showed that, more than two third of the studied nurses $(68.5 \%)$ have incompetent practices related to children safety.

The present study reveals that the majority of the studied nurses had unsatisfactory level related to hand washing this might be due to hand washing was not followed routinely in most of the nursing procedures. This finding was supported by Bahgatet al., (2013): who found that, $41.8 \%$ the studied nurse incompetent done hand washing. Regarding the practices of studied nurses about infection control, the majority of the studied nurses don't done that might be lack of supplies and equipments especially in medical units, lack of nursing awareness and more work stress on them (increase numbers of cases and short nurses numbers), this finding agreed with Bahgat et al.,(2013): while more than half $56.4 \%$ of the studied staff nurse don't done.

In relation to the practice of studied nurses about oxygen therapy, the present study reveals that three quarters had unsatisfactory level in oxygen therapy procedure. This finding was supported by finding of Fayed et al., (2018), who found about two third $(62.3 \%)$ of nurses had incompetent done to this procedure.

Regarding to the practice of studied nurses about suction, the majority of the studied nurses had unsatisfactory level. This finding was supported by finding of Bahgatet al., (2013) who found that the majority $(98.2 \%)$ of the nurses had poor practices of suction this may be due to lack of supplies and equipments and more work loud. Regarding the practice of studied nurses about peripheral intravenous line placement, the majority of the studied nurses had unsatisfactory level. This finding was supported by finding of Keleekai et al., (2016): who found that the control group had lower scores for knowledge and skills about peripheral intravenous line placement also Fayed et al., (2018), who found about two third $(64.3 \%)$ of nurses had incompetent done to this procedure.

\section{Conclusion:}

Based on result of the present study, it can be concluded that nurses' knowledge and practice related to children safety measures were unsatisfactory.

\section{Recommendations: \\ Based on the findings of the present study the following is recommended:}

- Developing periodical in-service training programs regarding children safety measures for the nurses working at pediatric departments to improve their knowledge, attitude and practices and to be aware of the significance of child safety in their work areas.

- Designing children safety guidelines as each hospital policy to provide safe work environment for nurses and children to reduce the occurrence of errors.

- Coordination between all healthcare team members especially physicians, pharmacists and improve their role to reduce medical errors and promote children safety.

- Supporting more research efforts particularly in areas that yield the greatest benefit and that more effectively contribute to improving child' safety and safe child' lives

\section{References:}

1) Ahmed, G. (2013)"Concept and attitude toward sick child's rights at pediatric surgical units" Master Thesis, Faculty of Nursing, Benha University,

2) Bahgat SR , Ramadan AI \& El - Salieh GA (2013)"; "Nurses' Perception and eveloping an Improvement Plan Regarding Child Safety in Benha Hospitals" Journal of American Science 2013;9(12). http://www.jofamericanscience.org

3) Boysen, P. (2013). Just Culture: A foundation for balanced accountability and patient safety. The Ochsner Journal, 13(3): 400-406.

4) Brasaite I, Kaunonen M \&Suominen T (2015)". "Healthcare professionals' knowledge, attitudes and skills regarding patient safety: a systematic literature review"Scand J Caring Sci. 2015 Mar;29(1):30-50. doi: 10.1111/scs.12136. Epub 2014 Apr 8. Review. PMID:24708205 
5) Donaghy, C., Doherty, R. \&Irwin, T., (2018) "Patient safety: a culture of openness and supporting staff Surgery" (Oxford)2018, 36, 509-514.

6) Durgun, H.\& Kaya, H., (2017) " The attitudes of emergency department nurses towards patient safety" International Emergency Nursing ,2018,40, 29-32. https://doi.org/10.1016/j.ienj.2017.11.001

7) Fayed AE \&Abd EL-Sadik RB;\& Abdel-Salam AA; (2018) "Effect of Guidelines for Nurses' Performance Regarding Children Safety in Benha Hospitals" Egyptian Journal of Health Care, EJHC 2018, Vol. 9 No. 3

8) Fayed, M., Hanan, T., Elbahnasawy, T.,\& Omar, K. (2016) "Effect of Instructional Program on Nurses Compliance with Universal Precautions of Infection Control" International Journal of Novel Research in Health care and Nursing; 2016, 3(1): 81-92.

9) Guinea, S., Andersen, P., Reid-Searl, K., LevettJones, T., Dwyer, T., Heaton, L., Flenady, T., Applegarth, J., \&Bickell, P., (2018) "Simulationbased learning for patient safety: The development of the Tag Team Patient Safety Simulation methodology for nursing education Collegian" https://doi.org/10.1016/j.colegn.2018.09.008

10) Hales B., Terblanche M., Fowler R.,\&SibbaldW. (2013) "Development of medical checklists for improved quality of patient care" Available at http://www.hpoe.org/checklists improve-patientsafety, 2013

11) Healthy Children org (2013) "Swaddling: Is it Safe? " American Academy of Pediatrics. Retrieved from: https://www.healthychildren.org/English/agesstages/baby/diapers clothing/Pages/Swaddling-Is-itSafe. 2013

12) Holly C,\&Poletick E. (2014). A systematic review on the transfer of information during nurse transitions in care. J ClinNurs [Internet]. 2014 Sep [cited 2015 Jun 10]; 23(17-18):2387-95. Available from: http://onlinelibrary.wiley.com/doi/10.1111/jocn.1236 5/full[ Links ].

13) James CD, Hanson K, \& Solon O (2011). Do doctors under-provide, overprovide or do both? Exploring the quality of medical treatment in the Philippines. Int J Qual Health Care;23:445-55.

14) Keleekai N. L., Schuster C. A., Murray C. L., King M. A., Stahl B. R., Labrozzi L. J., Gallucci S., LeClair M. W., \& Glover K. R. (2016). Improving Nurses' Peripheral Intravenous Catheter Insertion Knowledge, Confidence, and Skills Using a Simulation-Based Blended Learning Program. Simulation in Healthcare: The Journal of the Society for Simulation in Healthcare, 11(6), 376384. https://doi.org/10.1097/sih.0000000000000186

15) Lundy KS (2014). "A history of health care and nursing". In Masters, K. Role Development in Professional Nursing Practice (3rd ed.). Burlington, MA: Jones \& Bartlett Learning. pp. 11-12. ISBN9781449681982

16) Meckler G., Leonard J., \& Hoyle J., (2014). Pediatric Patient Safety in Emergency Medical Services. Clinical Pediatric Emergency Medicine 15, 18-27. https://doi.org/10.1016/j.cpem.2014.01.003

17) National Patient Safety Foundation. (2013) National agenda for action: Patients and families in patient safety - Nothing about me, without me. Chicago, IL. Author, 1-12

18) Popay J, Roberts H, \&Sowden A, (2014). Guidance on the Conduct of Narrative Synthesis in Systematic Reviews: A product from the ESRC methods programme. Version 1 (10 November 2014, date last accessed).

19) Sexton JB, Helmreich RL, Neilands TB, Rowan K, Vella K, Boyden J, Roberts PR, \& Thomas EJ. (2006) "the Safety Attitudes Questionnaire: psychometric properties, benchmarking data, and emerging research" BMC Health Serv Res. 2006 Apr $3 ; 6: 44$.

20) Shekelle PG, Pronovost PJ, Wachter RM, Taylor SL, Dy SM, Foy R, Hempel S, McDonald KM, Ovretveit J, \& Rubenstein LV, (2011). Advancing the science of patient safety. Ann Intern Med, 154 (10): 693-696. 10.7326/0003-4819-154-10-201105170-00011.View ArticlePubMedGoogle Scholar

21) The Joint Commission, (2019). National Patient Safety Goals Effective January 2019.

22) World Health Organization. (2017). Patient Safety Making health care safer : available under the Creative Commons Attribution-NonCommercialShareAlike 3.0 IGO licence (CC BY-NC-SA 3.0 IGO; https://creativecommons.org/licenses/by-ncsa/3.0/igo).

23) World Health Organization. (2017). Patient Safety Making health care safer : available under the Creative Commons Attribution-NonCommercialShareAlike 3.0 IGO licence (CC BY-NC-SA 3.0 IGO; https://creativecommons.org/licenses/by-ncsa/3.0/igo).

24) World Health Organization (2014). Patient safety in developing and transitional countries: New insights from Africa and the Eastern http://www.who.int/patientsafety/research/emro_afro _report.pdf (10 November 2014, date last accessed) 